

\title{
EDITORIAL COMMITTEE
}

\author{
Editor-in-Chief
}

Dr John Lyne, Royal College of Surgeons in Ireland; Wicklow Mental Health Services

$$
\text { Deputy Editor }
$$

Dr Brian Hallahan, National University of Ireland, Galway

Consulting Editor

Dr Larkin Feeney, Consultant Psychiatrist, Cluain Mhuire Community Mental Health Service; Senior Lecturer, Royal College of Surgeons in Ireland

Associate Editors

Dr Eric Roche, Cluain Mhuire Community Mental Health Service (Blackrock, Co. Dublin), Republic of Ireland

Dr Martha Finnegan, Higher Specialist Trainee in Psychiatry, University Hospital Galway, Republic of Ireland

Professor Louise Gallagher, Professor of Child and Adolescent Psychiatry,

St. James's Hospital, Dublin; Trinity College Dublin

Dr Erik Kolshus, Trinity College Institute of Neuroscience, Trinity College Dublin;

Limerick Mental Health Services, Republic of Ireland

Dr Brian O'Donoghue, Orygen, the National Centre of Excellence in Youth Mental Health, Melbourne, Australia; Centre for Youth Mental Health, University of Melbourne, Australia

Editorials Editor

Professor Mary Cannon, Royal College of Psychiatrists and Beaumont Hospital, Dublin

Social Media Editor

Dr lan Kelleher, Royal College of Surgeons in Ireland

Trainee Editors

Dr Lauren Alexander, St. Vincent's Psychiatric Hospital, Fairview, Dublin; University College Dublin, Republic of Ireland

Dr Kevin Glynn, Senior Registrar in Old Age Psychiatry, Beaumont Hospital, Republic of Ireland

Statistical Advisor

Dr Dimitrios Adamis, Sligo Mental Health Services; University of Limerick; Research and Academic Institute of Athens, Greece

Publishing Staff

Ian Rice, Editorial Assistant

Founding Editor

Dr Mark Hartman

Former Editors-in-Chief

Professor Brian Lawlor

Professor Brendan Kelly

\section{COVER IMAGE}

The cover image of a lecture hall was chosen for this journal edition dedicated to undergraduate and postgraduate education in psychiatry. The image was obtained from Wokandapix at Pixabay.com 


\section{EDITORIAL BOARD}

\section{Dr Caragh Behan}

Consultant Psychiatrist, Cluain Mhuire Community Mental Health Service Professor Dinesh Bhugra

Institute of Psychiatry, Psychology and Neuroscience, King's College London, UK

Professor Peter F. Buckley

School of Medicine Virginia Commonwealth University (VCU) Executive

Vice President for Medical Affairs, U.S.A.

\section{Dr Peter Byrne}

Strathclyde University, Glasgow

Dr Angela Carballedo

North Dublin Mental Health Services; Royal College of Surgeons of Ireland;

Trinity College Dublin, Ireland

Professor Patricia Casey

Mater University Hospital, Dublin

Professor Mary Clarke

Dublin and East Treatment and Early Care Team (DETECT) Services;

St. John of God Community Services; University College Dublin

Laura Louise Condell

Member, CPsychl REFOCUS Group (Recovery Experience Forum of Carers

and Users of Services), Ireland

Professor David Cotter

Royal College of Surgeons in Ireland

Dr Robert Daly

North Dublin Mental Health Service

Dr Philip Dodd

Trinity College, Dublin; Consultant Psychiatrist, St. Michael's House, Dublin

Dr Blanaid Gavin

University College Dublin

Professor Michael Gill

St. James's Hospital, Dublin; Trinity College Dublin

Professor Gautam Gulat

University of Limerick; University College Cork

Professor Angela Hassiotis

UCL Division of Psychiatry, London

Dr Katherine Johnson

University of Melbourne, Australia

Dr Eric Kelleher

University College Cork, Republic of Ireland
Professor Harry Kennedy

Trinity College Dublin

Dr John Lally

Royal College of Surgeons in Ireland; Beaumont Hospital, Dublin

Professor Colm McDonald

National University of Ireland, Galway

Professor Patrick McGorry

Centre for Youth Mental Health, the University of Melbourne;

OYH Research Centre, Australia

Dr Jane McGrath

Trinity College Dublin

Professor Fiona McNicholas

Our Lady's Hospital for Sick Children, Lucena Clinic, and University College

Dublin, Ireland

Dr Stephen McWilliams

St John of God Hospital, Stillorgan, Co. Dublin

Professor David Meagher

University of Limerick, Ireland

Dr Karen O'Connor

University College Cork

Associate Professor Colin O'Gara

University College Dublin and St John of God Hospital

Dr Hugh Ramsay

Royal College of Surgeons in Ireland

Adjunct Assistant Professor Udo Reulbach

Trinity College Dublin

Dr K. Oliver Schubert

University of Adelaide, Australia

DrThekiso BoitshokoThekiso

Trinity College Dublin

Asst. Professor Jai Shah

McGill University, Canada

Dr Bobby Smyth

Department of Public Health \& Primary Care, Trinity College

Dublin; HSE Addiction Service, Cherry Orchard Hospital, Dublin.

INTERNATIONAL ADVISORY BOARD

Professor João Mauricio Castaldelli-Maia

Department of Neuroscience of Fundação do ABC Medical School, Brazil

Dr Avinash Desousa

Lokmanya Tilak Municipal Medical College, Mumbai, India

Professor Mantosh Dewan

SUNY Distinguished Service Professor, Interim Dean, College of Medicine,

Upstate Medical University, Syracuse NY, USA

Professor Mohan Isaac

Clinical Professor of Psychiatry at the University of Western Australia,

Perth, Australia

Professor Shigenobu Kanaba

Neuropsychiatry, Kyushu University, Fukuoka, Japan

Professor Roger Man Kin NG

Consultant Psychiatrist, Dept of Psychiatry, Kowloon Hospital, Hong Kong, China
Professor David Ndetei

University of Nairobi, Kenya

Professor Michelle Riba

Department of Psychiatry University of Michigan, USA

Professor Dan Stein

Dept of Psychiatry \& Mental Health, University of Cape Town \& UCT-Affiliated

Hospitals, South Africa

Professor JulioTorales

Professor of Psychiatry and Medical Psychology, National University of Asunción, Paraguay

Professor Lakshmi Vijayakumar

SNEHA, Suicide prevention center, Voluntary Health

Services, Chennai; Associate Professor, University of Melbourne, Australia

AIMS AND Scope: Established in 1982, the Irish Journal of Psychological Medicine is dedicated to acting as an international forum for the publication of research on the science and practice of psychiatry. Its main aim is to disseminate original scientific research to a national and international readership with the objective of improving clinical practice and service development in mental health. The journal advocates for delivering high quality clinical care and improvement in mental health services, and is committed to keeping the field of mental health vibrant and relevant by publishing research on novel topics. Particular strengths and unique features of the Journal include a focus on Clinical Psychiatry, Youth Mental Health and the History of Psychiatry, with regular features and special issues devoted to these topics.

The Irish Journal of Psychological Medicine publishes research papers, short reports, review papers, editorials, case reports, historical papers, perspective pieces and book reviews. There are four editions published per year, for which rapid peer review process and publication is considered a priority. The journal regularly publishes special themed editions guest edited by internationally respected academics in a particular research field. With a progressive focus, the journal provides important reading for clinicians, researchers, policymakers and all professionals with an interest in mental health. 